\title{
PENANAMAN NILAI SOSIAL ANAK USIA DINI MELALUI GERAK DAN LAGU
}

\author{
Oleh: Waluyo Satrio Adji \\ (Dosen PGMI FTK IAIN Antasari Banjarmasin)
}

\begin{abstract}
Abstrak
Masa Anak Usia Dini merupakan investasi masa depan yang perlu distimulasi perkembangannya sejak usia dini. Sel-sel otak yang dimiliki anak sejak bayi tidak akan mampu tumbuh dan berkembang secara optimal jika stimulus yang diberikan tidak tepat. Salah satu kawasan yang perlu dikembangkan oleh guru TK/RA dalam merangsang anak adalah dengan penanaman nilai sosial Tulisan ini bertujuan untuk mendeskripsikan penggunaan media gerak dan lagu untuk menanamkan nilai sosial pada anak usia dini. Media gerak dan lagu akan mampu menjadi media yang efektif digunakan untuk menanamkan nilai sosial anak jika deterapkan secara tepat. Dalam menggunakan media gerak dan lagu untuk menanamkan nilai sosial pada anak uasia dini ada beberapa hal yang perlu diperhatikan, diantaranya adalah: (1) membuat tujuan, dengan pertimbangan disesuaikan dengan tingkat perkembangan anak adan tidak monoton, olah vocal. (2) action, pembuatan bait lagu serta gerakan yang sesuai. Sehingga nilai disampaikan kepada anak bisa dicerna sesuai kebutuhan,
\end{abstract}

Kata Kunci: Anak Usia Dini, Nilai Sosial, Gerak dan Lagu

\section{A. Pendahuluan}

Masa emas (golden age) disinonimkan dengan usia dini, pada usia ini sebagian besar aktivitas dan kualitas manusia dibentuk melalui sel-sel otak. Sejak lahir seorang anak manuisia mempunyai kurang lebih 100 miliyar sel otak. Sel-sel otak saling berhubungan dengan sel-sel syaraf. Sel-sel otak ini tidak akan tumbuh dan berkembang dengan pesat tanpa adanya stimulasi dan didayagunakan (Gutama,dkk., 2005: 3). Waktu tersebut merupakan peluang terbaik untuk membentuk dan mengembangkan berbagai potensi yang dimiliki manusia.

UU No. 20 Tahun 2003 tentang Sistem Pendidikan Nasional, yang menyatakan bahwa pendidikan anak usia dini adalah salah satu usaha pembinaan yang ditujukan untuk anak sejak lahir sampai dengan 6 tahun, yang diupayakan melalui pemberian stimulus untuk membantu pertumbuhan dan perkembangan jasmani dan rohani agar anak memiliki kesiapan dalam memasuki jenjang pendidikan lebih lanjut. (Pasal 1 butir 14).

Manusia sebagai makhluk sosial, yang tidak hidup sendiri, dalam perkembangannya sejak usia dini salah satu kawasan yang harus dikembangkan adalah nilai sosial, karena nilai-nilai sosial memberikan pedoman hidup berkasih sayang, harmonis, dispilin dalam berinteraksi dengan sesama manusia sehingga eksistensinya dapat diakui di masyarakat, 
sebaliknya tanpa adanya nilai-nilai sosial suatu masyarakat tidak akan memperoleh kehidupan yang harmonis dan demokratis. Zubaedi (2006:13)

Penaaman nilai-nilai sosial sejak usia dini, diharapkan pada tahap perkembangan selanjutnya anak akan mampu membedakan benar salah, baik buruk dalam kehidupan sehari-harinya. Sehingga Ini akan berpengaruh pada mudah tidaknya anak diterima oleh masyarakat sekitarnya dalam hal bersosialisasi. Perkembangan sosial merupakan proses yang berkelanjutan dalam kehidupan manusia. Proses ini dimulai sejak anak berusia enam minggu, yakni pada saat anak dapat melihat ibu dengan matanya kemudian tersenyum kepadanya.(Khabib Ahmad Sathut, 1998:27).

Upaya penanaman nilai-nilai sosial diperlukan beberapa pertimbangan, pada usia ini sedang dalam tahap perkembangan pra operasional kongkrit seperti yang dikemukakan oleh Piaget, sedangkan nilainilai sosial merupakan hal abstrak, sehingga dalam hal ini anak belum bisa menerima apa yang diajarkan guru/orang tua, salah satu media dalam menananmkan nilai sosial adalah melalui gerak dan lagu. Asfandiyar (2008) mengemukakan tiga komponen penting dari gerak tubuh, yaitu logika motoric (kemampuan saraf otot untuk bergerak), memori kinestetik (kemampuan mengatur batas dari gerakan), kesadaran kinestetik (kemampuan indera gerak mengikuti perintah). Kecerdasan gerak tidak sekedar melibatkan gerakan tapi juga kemampuan berpikir. Menyediakan ruang yang cukup untuk anak melakukan gerakan adalah upaya yang dapat dilakukan guru dan orang tua dalam menfasilitasi pengembangan kemampuan gerak anak. Bermain dan lagu merupakan media penting untuk membantu anak-anak pengetahuan tentang dunia mereka. Pemilihan media yang tepat menjadikan tercapainya tujuan pembelajaran, salah satunya melalui gerak dan lagu, sehingga dalam menanamkan nilai sosial kepada anak, nilai sosial yang ingin disampaikan guru tersampaikan dan dipahami oleh siswa sebagai pedoman dalam hidup di masyarakat.

\section{B. Nilai}

Dalam Kamus Besar Bahasa Indonesia karangan Purwodarminto dinyatakan bahwa nilai adalah harga, hal-hal yang berguna bagi manusia. Menurut I Wayan Koyan (2000:12), nilai adalah segala sesuatu yang berharga. Menurutnya ada dua nilai yaitu nilai ideal dan nilai aktual. Nilai ideal adalah nilai-nilai yang menjadi cita-cita setiap orang, sedangkan nilai aktual adalah nilai yang diekspresikan dalam kehidupan sehari-hari. Kohlberg mengklasifikasikan nilai menjadi dua, yaitu nilai obyektif dan nilai subyektif. Nilai obyektif atau nilai universal yaitu nilai yang 
bersifat instrinsik, yakni nilai hakiki yang berlaku sepanjang masa secara universal.

Termasuk dalam nilai universal ini antara lain hakikat kebenaran, keindahan dan keadilan. Adapaun nilai subyektif yaitu nilai yang sudah memiliki warna, isi dan corak tertentu sesuai dengan waktu, tempat dan budaya kelompok masyarakat tertentu. Menurut Richard Merill dalam I Wayan Koyan (2000:13) menyatakan bahwa nilai adalah patokan atau standar yang dapat membimbing seseorang atau kelompok ke arah "satisfication, fulfillment, and meaning".

\section{Nilai Sosial}

Nilai sosial adalah nilai yang dianut oleh suatu masyarakat, mengenai apa yang dianggap baik dan apa yang dianggap buruk oleh masyarakat.

(https://id.wikipedia.org/wiki/Nilai_sosial)

Beberapa ahli

(https://id.wikipedia.org/wiki/Nilai_sosial) mendefinisikan tentang nilai sosial, sebagai berikut:

1. Kimball Young

Mengemukakan nilai adalah asumsi yang abstrak dan sering tidak disadari tentang apa yang dianggap penting dalam masyarakat.

\section{A.W.Green}

Nilai adalah kesadaran yang secara relatif berlangsung disertai emosi terhadap objek.

3. Woods

Mengemukakan bahwa nilai merupakan petunjuk umum yang telah berlangsung lama serta mengarahkan tingkah laku dan kepuasan dalam kehidupan sehari-hari

4. M.Z.Lawang

Menyatakan nilai adalah gambaran mengenai apa yang diinginkan,yang pantas,berharga,dan dapat memengaruhi perilaku sosial dari orang yang bernilai tersebut.

5. Hendropuspito

Menyatakan nilai adalah segala sesuatu yang dihargai masyarakat karena mempunyai daya guna fungsional bagi perkembangan kehidupan manusia.

6. Karel J. Veeger

Menyatakan sosiologi memandang nilainilai sebagai pengertian-pengertian (sesuatu di dalam kepala orang) tentang baik tidaknya perbuatan-perbuatan. Dengan kata lain, nilai adalah hasil penilaian atau pertimbangan moral.

Menurut Zubaedi (2006:13), Nilai-nilai Sosial, terdiri atas:

1. Kasih Sayang, terdiri atas:

a. Pengabdian

b. Tolong Menolong

c. Kekeluargaan

d. Kesetiaan 
e. Kepedulian

2. Tanggung Jawab, teridiri atas:

a. Nilai rasa saling memiliki

b. Disiplin

c. Empati

3. Keserasian Hidup, terdiri atas:

a. Keadilan

b. Toleransi

c. Kerjasama

d. Demokrasi

Menurut Idianto M (2004: 108) ciri-ciri nilai sosial adalah sebagai berikut:

1. Tercipta dari proses interaksi antar manusia, bukan perilaku yang dibawa sejak lahir.

2. Ditransformasikan melalui proses belajar.

3. Berupa ukuran atau peraturan sosial yang turut memenuhi kebutuhan sosial.

4. Berbeda-beda pada tiap kelompok manusia.

5. Masing-masing nilai mempunyai efek yang berbeda-beda bagi tindakan manusia.

6. Dapat mempengaruhi kepribadian individu sebagai anggota masyarakat.

7. Merupakan konstruksi masyarakat sebagai hasil interaksi antarwarga masyarakat.

8. Bervariasi antara kebudayaan yang satu dengan kebudayaan yang lain.

9. Cenderung berkaitan satu sama lain.

\section{Anak Usia Dini}

Menurut Isjoni, 2009: 19-24, Anak usia dini adalah individu yang sedang mengalami proses pertumbuhan dan perkembangan yang sangat pesat. Anak usia dini merupakan anak yang berusia 0-6 tahun. Anak usia dini adalah individu yang sedang mengalami 5 proses pertumbuhan dan perkembangan yang sangat pesat. Bahkan dikatakan sebagai lompatan perkembangan. Karena itulah, maka usia dini dikatakan sebagai usia emas, yaitu usia yang sangat berharga disbanding usia-usia selanjutnya. Anak usia dini dikenal sebagai manusia yang unik, kadang-kadang melebihi dari orang-orang dewasa yang sulit diterka, diduga, bila dilihat dari bicara, tingkah laku maupun pikirannya. Anak usia dini memiliki karakteristik tersendiri (Isjoni, 2009:24-26), diantaranya:

1. Usia 0-1 tahun Pada masa bayi perkembangan fisik mengalami kecepatan luar biasa, paling cepat dibanding usia selanjutnya. Berbagai karakteristik usia bayi diantaranya:

a. Mempelajari keterampilan motorik mulai dari berguling, merangkak, duduk, berdiri, dan berjalan

b. Mempelajari menggunakan panca indera.

c. Mempelajari komunikasi sosial.

2. Usia 2-3 tahun Pada usia ini memiliki karakteristik yang sama pada usia selanjutnya, secara fisik mengalami pertumbuhan yang sangat pesat. 
Karakteristik khusus pada usia ini antara lain;

a. Anak sangat aktif mengeksplorasi bendabenda yang ada disekitarnya.

b. Mulai mengembangkan kemampuan berbahasa.

c. Mulai mengembangkan emosi.

3. Usia 4-6 tahun Karakteristik usia ini antara lain:

a. Berkaitan dengan perkembangan fisik, anak sangat aktif melakukan kegiatan.

b. Perkembangan bahasa semakin baik.

c. Perkembangan kognitif sangat pesat.

d. Bentuk permainan anak masih bersifat individu.

\section{E. Gerak dan Lagu}

Gerak atau kinestetikal sendiri sangat berhubungan dengan kemampuan anak untuk mengetahui di mana bagian-bagian tubuhnya dan sebagaimana bagian-bagian tubuh bergerak. Sedangkan lagu adalah ragam suara yang berirama (KBBI, 2015). Istilah lagu sering dikaitka dengan melodi, ritme, atau tempo. Menurut Haga (2008) persepsi musical terjadi dalam keseharian. Salah satunya dapat diekspresikan melalui gerak -semua macam gerak, baik yang dilakukan para penari professional. Anak-anak pada umumnya senang mengapresiasi irama yang mereka dengan, sehingga, memadukan gerak dan lagu dapat menjadi pilihan yang baik bagi pembelajaran usia dini. (Mubiar, 2015:6)
Esensi dari irama adalah suara. Suara atau bunyi dapat dibuat menggunakan bunyi dari mulut, tepukan tangan, hentakan kaki, denting botol yang dipukul sendok, atau dari alat-alat musik tertentu. Kepekaan dan oenguasaan terhadap nada, irama, pola, ritme, te,po, instrument, dan ekspresi musik perlu dilatih sehingga seseorang mampu menyanyikan lagu, memainkan, dan menikmati musik. Imitasi dan eksplorasi terhadap berbagai bunyi, gambar, dan gerakan, seyogyanya menjadi bagian daripengalaman anak seharihari, termasuk dalam kegiatan pembelajaran di kelas. (Mubiar, 2015:6)

Musik berkaitan erat dengan perkembangan kognitif serta dapat menjadi sarana yang baik untuk mengembangkan kecakapan sikap, tingkah laku, dan disiplin. Permainanpermainan yang dapat membantu anak mempelajari irama, lemah-kuatnya nada, dan tinggi-rendahnya bunyi, dapat menjadi alternative. Bernyanyi merupakan kegiatan yang sudah sangat erat dengan praktik pembelajaran ana usia dini. Hampir semua kegiatan pembelajaran selalu diselangi lagu seperti Sebelum dan sesudah makan, berdoa, dsb. (Mubiar, 2015:7)

Asfandiyar (2008) mengemukakan tiga komponen penting dari gerak tubuh, yaitu logika motoric (kemampuan saraf otot untuk bergerak), memori kinestetik (kemampuan mengatur batas dari gerakan), kesadaran kinestetik (kemampuan indera gerak 
mengikuti perintah). Kecerdasan gerak tidak sekedar melibatkan gerakan tapi juga kemampuan berpikir. Menyediakan ruang yang cukup untuk anak melakukan gerakan adalah upaya yang dapat dilakukan guru dan orang tua dalam menfasilitasi pengembangan kemampuan gerak anak. Bermain dan lagu merupakan media penting untuk membantu anak-anak pengetahuan tentang dunia mereka.

\section{F. Penanaman nilai sosial melalui gerak dan lagu}

Menanamkan nilai-nilai sosial pada anak, tidak cukup dengan menyampaikan kata-kata dan nasihat serta teguran-teguran apabila anak melakukan kesalahan. Pada usia anak 0-6 tahun daya tangkap dan daya ingatan anak terhadap perkataan masih sangat lemah, sehingga salah satu solusi penyampaiannya melalui lagu atau nyanyian.

Langkah menanamka nilai sosial yang pertama adalah:

\section{Menentukan tujuan}

Pastika gerak dan lagu yang kita buat dan kita sajikan pada anak, memiliki tujuan yang jelas: gerakan yang dilakukan memiliki tujuan, lagu yang dinyanyikan juga memiliki tujuan. Semua gerak dan lagu dibuat dan dilakukan dengan bermakna sehuingga mampu memberi pembelajaran, bukan sekedar membuat anak senang.

2. Lakukan saja (Action)
Jangan takut berkreasi, semua ide layak dihargai, semua kreasi layak diapresiasi. Semua fenomena keseharian dapat menjadi inspirasi

Berikut contoh lagu yang terdapat penanaman nilai-nilai sosial (menyayangi),

\section{Bergerak Tuk Menyayangi}

Tangan digoyang-goyang

Pinggul digoyang-goyang

Kaki digoyang-goyang

Semua jadi Bergerak

Di bepan ada teman

Di belakang ada teman

Di kiri ada teman

Di kananpun ada teman

Kita harus sayang teman

Kita harus sayang guru

Kita harus sayang orang tua

Supaya Tuhan cintai kita

Ayo kawan-kawan berpegang tangan

Kita Cintai semua orang

Ayo kawan-kawan saling menyayangi

Supaya kita tetap bersahabat

\section{Sinopsis:}

Pada bait lagu ini akan membantu anak mengembangkan cinta dan sayang sesame, terutama teman guru dan orang tua. Secara normative lagu ini pun memuat nilai religious berniat menyayangi atas nama Tuhan semata/ibadah. 
JEA Vol.2 Issue 2 Juli-Desember 2016 |116 


\section{Daftar Pustaka}

Agustin, dkk. 2015. Gerak dan Lagu Serta Bercerita Untuk Mengembangkan Poteni Anak. Bandung: Rizqi Press

Asfandiyar, Andi Yudha. 2008. Kenapa Guru Harus Kreatif. Bandung: Mizan

Gutama,dkk. 2005. Mewujudkan Pendidikan Anak Usia Dini yang Holistik. Seminar dan Lokakarya Nasional 2005 Pendidikan Anak Usia Dini, kampus UGM 14-16 Nopember 2005

https://id.wikipedia.org/wiki/Nilai_sosial, diakses pada 19 Mei 2016

I Wayan Koyan. 2000. Pendidikan Moral Pendekatan Lintas Budaya. Jakarta: Depdiknas. Isjoni. 2009. Model Pembelajaran Anak Usia Dini. Bandung: ALFABETA

Kamus Besar Bahasa Indonesia. 2015. Tersedia: http://www.kbbi.wen.id diakses pada 19 Mei 2016

Sathut, Khabib Ahmad. 1998. Menumbuhkan Sikap Sosial, Moral, Spiritual Anak Dalam Keluarga Muslim, penerjemah, Ibnu Burdah. Yogyakarta: Mitra Pustaka Zubaedi. 2006. Pendidikan Berbasis Masyarakat. Yogyakarta: Pustaka Belajar 